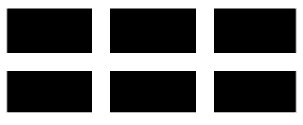

ThE William DAVIDSON INSTITUTE AT THE UNIVERSITY OF MICHIGAN BUSINESS SCHOOL

\title{
Labor Mobility during Transition: Evidence from the Czech Republic
}

\author{
By: Jan Fidrmuc
}

William Davidson Institute Working Paper Number 767

April 2005 


\title{
Labor Mobility during Transition: Evidence from the Czech Republic $^{\nabla}$
}

\author{
Jan Fidrmuc*
}

April 2005

\begin{abstract}
In this paper, I analyze the development of inter-regional mobility in the Czech Republic during the transition from central planning to a market economy. I show that the intensity of migration is low and even has fallen during the transition regional disparities in unemployment rates and earnings have increased. More importantly, labor mobility is little effective in facilitating labormarket adjustment to employment shocks. Using aggregate inter-regional migration data and survey data on past and prospective migration and the willingness to move. I find that economic factor play little role in explaining migration patterns. There is, nonetheless, some tentative evidence of the greater importance of economic considerations in explaining future migration intentions and the willingness to move. Thus, while at present migration appears more of a social or demographic rather than economic phenomenon, its economic role may strengthen in the future.
\end{abstract}

Keywords: Migration, Mobility, Labor-market Adjustment, Regional Shocks, Survey data. JEL Codes: F22, J61, P23.

${ }^{\nabla}$ Prepared for the special issue of Zeitschrift für Arbeitsmarktforschung (formerly Mitteilungen aus der Arbeitsmarkt- und Berufsforschung) on Europeanization of the Labor Markets in an Enlarged European Union, edited by Friedrich Buttler, Elmar Hönekopp and Thomas Straubhaar. I am grateful to Elmar Hönekopp and two anonymous referees for many helpful comments and suggestions. This research was initiated while I was a Marie Curie Fellow at ECARES, Université Libre de Bruxelles whose hospitality I gratefully ackowledge.

${ }^{*}$ Brunel Business School, Brunel University; CEPR, London; and WDI, University of Michigan. Contact information: Brunel Business School, Economics and Finance Section, Brunel University, Uxbridge, UB8 3PH, United Kingdom. Email: Jan.Fidrmuc@brunel.ac.uk. Phone: +44-1895-266-528, Fax: +44-1895-203-384. 


\section{Introduction}

Inter-regional labor mobility, or migration, ${ }^{1}$ is an important economic phenomenon and a crucial determinant of regional labor-market developments. As such, it is an interesting topic and fruitful object for academic study and policy discussion. Migration in the transition countries of Central and Eastern Europe attracted a great deal of attention lately in the context of EU enlargement. Ironically enough, the discussion tends to look upon migration from two, very different, angles. The first view sees migration as a positive development, indeed as an indispensable channel of regional adjustment. This role of migration is particularly important in relation to monetary integration in Europe, in which the new members are required to take part sooner or later. Once they adopt the euro, the new member countries will be subject to the one-size-fits-all monetary policy of the European Central Bank. Most available studies (see Horvath and Ratfai, 2004, Fidrmuc and Korhonen, 2003, 2004) indicate that the new members' business cycles are, at best, imperfectly aligned with the Eurozone. Unless there is rapid improvement in this respect (as envisaged by Babetskii, Boone and Maurel, 2004), the newcomers will require adjustment mechanisms other than independent monetary policy to help their labor market deal with asymmetric shocks. Labor mobility is such an adjustment mechanism. When the labor force is highly mobile and responds readily to labor-market developments, membership in the Eurozone will be not be associated with high costs even if the new member countries continue to experience idiosyncratic shocks. Somewhat less intuitively, high mobility of labor in the new member countries of the EU can also be good also for the destination countries. Europeans in general are known to be little mobile. Schuendeln (2004), however, finds that immigrants in Germany tend to be more mobile than the natives and also respond more readily to differentials in labor-market conditions. As such, immigrants constitute a mobile segment of the labor markets and thus can help facilitate adjustment to employment shocks also in the destination countries.

The second view, in contrast, is concerned with the implications of migration for the destination countries' labor markets and public budgets. Once the nationals of the new member countries of the EU are free to move to the old member countries, it is feared they will do so in large numbers, attracted by high wages and/or generous welfare states (Sinn and Werding, 2001,

\footnotetext{
${ }^{1}$ The terms labor mobility and migration are used interchangeably in this paper.
} 
consider the former, Chand and Paldam, 2005, discuss the latter, and Sinn, 2004, analyzes both motives). Accordingly, a large enough East-West flow of migrants would destabilize the destination countries' labor markers by increasing unemployment and driving down wages of the natives, and would allow the migrants to free-ride on the generous welfare-state provisions in the destination countries. Therefore, migration from the new members is a threat, and as such should be restricted. $^{2}$

These two views thus arrive at very different conclusions about the merits of migration in the context of European integration. Whether migration is seen as a threat or opportunity, nonetheless, it is important to know how prevalent it really is. Therefore, in this paper, while I refrain from making extensive qualitative predictions about the impact of migration on origin or destination countries (see Klailová, 2004, for an extensive discussion of the implications of postenlargement migration flows from the Czech Republic to the 'old' EU countries), I assess the extent of migration and analyze its responsiveness to labor-market characteristics in one transition economy: the Czech Republic. The Czech Republic is particularly suited for this kind of analysis. It is a medium-sized transition economy that has gone from having one of the most orthodox centrally-planned economies and strictest communist regimes to becoming a market economy, democracy, and a member country of the EU in barely a decade and a half. As such, its experience should be similar to (if not representative of) issues and developments encountered by most of the other transition countries.

In the following section, I start my analysis of migration ${ }^{3}$ in the Czech Republic by discussing some descriptive evidence on the extent of, and the reasons for, labor mobility in the Czech Republic I then present results of my empirical analysis of determinants of migration in section 3. Finally, I summarize the main findings and draw conclusions from them in section 4.

\footnotetext{
${ }^{2}$ It should be pointed out, however, that these fears find little justification in empirical evidence from previous episodes of large-scale migration flows. Friedberg and Hunt (1995) survey the available evidence and find that immigration has at most modest effect on the host country wages and unemployment. Similarly, most studies assessing the impact of the massive immigration from the Soviet Union to Israel in the early 1990s find that it had little long-term impact, if any, on the wages and employment of native Israelis (see, for example, Cohen and Paserman, 2004).

${ }^{3}$ A related, and equally important economic phenomenon, is commuting. Unfortunately, as none of the data available to me measure the extend of commuting in the Czech Republic, I am unable to consider commuting as part of my analysis.
} 


\section{How Often and for Why Do Czechs Move?}

Whether it is perceived in positive or in negative light, it is generally accepted that migration is important, from the point of view of both the region or country of origin and destination. A crucial question, therefore, is: How much migration, inter-regional and international, do we see in the transition countries? Figure 1 gives an answer to this question based on the official migration statistics, which measure migration using records on arrivals and departures in the Czech population registry. By law, Czech residents regardless of nationality are requ ired to register with the municipality in their place of residence. The migration statistics are derived from the changes in the registry; they comprise migration by Czech nationals and foreigners who hold permanent and (since 2001) long-term (at least one year) residency rights in the Czech Republic. ${ }^{4}$

Insert Figure 1 about here.

The official statistics allow us to make three important observations. First, Czechs have become increasingly reluctant to move over time, with migration flows falling steadily from the high of 130,000 in 1992 until they leveled off at around 100,000 in the mid 1990s. With overall population of 10.3 million, this means that in the second half of the 1990 s $1 \%$ of the Czech population changes their place of residence annually. Migration has increased towards the end of the 1990s and in the early 2000s, but this increase was almost entirely driven by increased immigration from abroad.

Second, the bulk of migration is made up by flows that largely cancel each other. In other words, most regions report a similar inflow and outflow of migrants, so that the resulting net inflow is very small. For example, the correlation between gross immigration and emigration

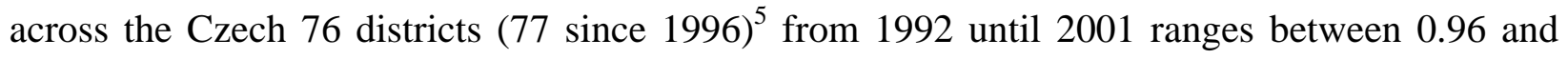
0.99. The correlation between gross and net immigration, in contrast, ranges between -0.72 and

\footnotetext{
${ }^{4}$ These figures are likely to underreport the actual extent of migration somewhat, as not all migrants inform the authorities of their move, or do not do so promptly. However, since access to some public goods such as healthcare and schooling is easier in one's place of official residence, the official statistics probably give a good measure of permanent migration while they may underreport temporary moves.

${ }^{5}$ The districts, or okresy, are the lower-level regions, below kraje (NUTS 3) and oblasti (NUTS 2), and above municipalities (obce). The average population of districts was approximately 140,000 in the mid 1990s. There were 76 districts until 1996, when the district of Jeseník was formed at the expense of Bruntál and Šumperk districts. The Czech regional structure was reformed in 1999 and district boundaries were redrawn (while keeping their number still at 77). For this reason, migration figures at the regional level up to 1999 and from 2000 are not comparable.
} 
0.89, and the correlation has steadily declined during this period (the highest value was attained in 1992 while the lowest pertains to 2001). This trend is even more apparent when considering only internal migration: while the gross inflows and outflows are again highly correlated, between 0.94 and 0.99, the correlation between the gross and net inflows, after reaching its highest value (0.73) in 1992, is in fact negative for most of the period (with the lowest value, 0.77, attained in 1996). This indicates that, for the most part, migration takes the form of churning rather than a net flow from depressed areas to those with more favorable labor-market conditions (Fidrmuc and Huber, 2004a, and Huber, 2004, also make this observation). This may be because most people move for reasons other than seeking employment: family or personal reasons (for example marriage, divorce or retirement), university studies, or finding a better house. Alternatively, churning may occur also because of reallocation of labor among sectors (and regions) due to structural change: traditional industries decline and new ones arise, resulting in a mismatch between skills of the resident labor force and the skill requirements of the expanding sectors. Such structural change did take place in the Czech Republic during the postcommunist transition; whether it can account for the churning nature of migration flows, however, is unclear.

Third, despite being poorer than its neighbors to the West, the Czech Republic appears on average to be a destination rather than a source country of emigrantion: each year, 9-12\% of all registered migrations come from abroad. It is likely that the official figures underestimate the actual extent of emigration (especially for Czech nationals), however, as migrants may fail to deregister because they expect to return in not-too-distant future, want to keep entitlements to residency-based public goods, or they simply do not bother to take the effort to inform the local authorities of their departure. Nonetheless, being richer and having a more dynamic economy, the Czech Republic was absorbing considerable inflows of migrants from other East European countries, especially Slovakia and Ukraine. ${ }^{6}$ In addition, the Czech Republic was also a

${ }^{6}$ Immigration appears to have accelerated in the recent years. It is unclear, however, to what extend this growth is due to methodological changes and to changes in the legal framework governing immigration that both took place in 2001. Until then, migration statistics included only permanent residents. Since 2001, foreigners who are long-term residents (defined as those holding residence permits for at least one year) are alos considered. This broadened the range of migrants included in Figure 1, which may account for some of the increase recorded in 20023. However, stricter eligibility requirements for long-term residency enacted since 2001 caused a large number of long-term residents to lose their long-term permits, which accounts for the negative migration balance recorded in 2001. Unfortunately, migration statistics do not differentiate between foreigners whose visa status changed from that of a long-term resident to short-term one and those who actually left the country; both are reported as emigrations 
destination for migrants from Western European countries. In fact, Boeri and Brücker (2000) report, relying on OECD data, that the Czech Republic is one of only two accession-candidate countries (the other country being Slovenia) to have a positive migration balance vis-à-vis the EU. Besides former refugees who left during the communist period and returned after the regime change, an important component of this migration flow are managerial staff and experts who come to the Czech Republic along with FDI inflows.

It is notable that migration has been falling in the Czech Republic on the background of rising inter-regional disparities with respect to both unemployment and wages (see also Fidrmuc, 2004). With increasing inter-regional differentials in labor-market conditions, individuals in economically depressed regions can improve their well-being considerably by migrating and taking up jobs in regions with low unemployment and high wages. In this way, migration helps equalize labor-market conditions across regions. If migration fails to respond to inter-regional differentials, on the other hand, labor-market shocks have long-term or permanent effects. This issue is analyzed in greater detail in the next section.

In order to assess the extent of labor mobility in the Czech Republic, it would be useful to compare Czech figures with those of the other new and old member countries of the EU. Comparing inter-regional migration figures across countries is difficult, however. Regional units often differ in size, which may bias the migration statistics: the larger the regions, the greater the fraction of migration classified as moving within region rather than between regions. I avoid this problem by looking at survey evidence: it relies on two recent Eurobaromenter surveys ${ }^{7}$, carried out with almost identical questions on past and prospective mobility in the old member countries in 2001 and, in the countries that were at the time candidates for membership in the EU in 2002.

The upper panel of Table 1 reports the extent of past mobility (over the past ten years) in the Czech Republic. For comparison, average figures for the ten new member countries, all 13 candidate countries, and the 15 old EU member countries are also reported. ${ }^{8}$ The first column reports the fraction of respondents who moved at least once in the past ten years. The second column reports the average number of moves (only for those who have actually moved). With

\footnotetext{
${ }^{7}$ I am grateful to The Gallup Organisation Europe for kindly making these data available to us. The survey data were collected by means of face to face interviews. Both samples were constructed so as to be representative at the national level.

${ }^{8}$ The averages are weighted by population. Country-specific figures are reported in the unpublished Appendix available from the author upon request.
} 
$20 \%$ of respondents reporting having moved, and on average moving only 1.3 times during the past ten years, the Czechs rank among the least mobile people in Europe: 25\% of respondents in the new member countries and $29 \%$ of those in the candidate countries have moved, while the migration rate in the old $\mathrm{EU}$ is $38 \%$.

The rest of the table offers additional information about the distance of migration (note that the figures reported in the third to seventh columns are the percentages only among those who moved rather than within the entire sample). ${ }^{9}$ Here, the Czech Republic comes out in somewhat more favorable light: approximately two-thirds of migrations in both candidate countries and the EU are within the same town or city whereas in the Czech Republic the corresponding figure is 54\%. Thus, nearly half of all past migrations entails moving over a non-trivial distance. Nevertheless, the vast majority of the remaining moves were within the same region (35\%). Only a relatively small fraction of respondents moved from another region in the Czech Republic, and even fewer moved from another country (1\% from another European country and 1.5\% from a country outside Europe). International mobility is low among the candidate countries in general: on average, $1.7 \%$ moved within Europe and $0.7 \%$ lived in a non-European country (the corresponding figures for the new member countries are slightly higher, $2.8 \%$ and $1.1 \%$, respectively). In contrast, 5.9\% of EU citizens previously lived in another EU country and 5.3\% lived outside the EU. ${ }^{10}$

Insert Table 1 about here.

It is reassuring to note that the survey results largely confirm the figures on inter-regional migration discussed above. With $46 \%$ of Czech population moving to another town or city over a ten-year period, and on average moving 1.26 times (assuming the number of moves is the same for all types of moves), we can an annual migration rate of $1.2 \%$. This is somewhat above the average migration rate of $0.9 \%$ obtained with official statistics on inter-regional migration. Some of the difference is due to the fact that official statistics only report moves across district

\footnotetext{
${ }^{9}$ Note the slight difference in the wording of the question in the two surveys: the last two categories for the candidate countries' survey are another country in Europe and a country outside of Europe, whereas the corresponding categories for the member countries' Eurobarometer were another EU country and a country outside the EU.

${ }^{10}$ This difference, however, may in part be explained by the different eligibility criteria for inclusion in the survey. In the candidate countries, only nationals of the country were allowed to participate. For the EU member countries, the respondents can be nationals of any EU country, who, in most cases, are themselves migrants.
} 
boundaries. The way the survey question is worded, one cannot determine whether those who moved from another town in fact moved from another town within the district or from another district. Another source of the difference is underreporting of migration in the official statistics whereby some migrations are not reported to the population registry. Since the difference between the two estimates of inter-regional migration is relatively small, underreporting does not seem to be excessive.

Prospective mobility is more interesting and relevant than the past migration pattern, especially in countries undergoing important economic restructuring. The on-going changes may give rise to greater or lower incentives to move in the future. This, however, does not seem to be the case with the Czech Republic: the patterns of prospective and past mobility are very similar. The lower panel of Table 1 presents figures on migration intentions over the period of the next five years. $13 \%$ of Czech respondents intend to move in the future, which again puts them close to the lower bound of their league. In contrast to past mobility, migration intentions are not dramatically different across the two groups of countries: on average 19\% of respondents of the candidate countries (16\% in the new member countries) plan to move, compared to $18 \%$ of EU citizens. With respect to the intended distance of moving, Czechs no longer appear dramatically different from either the other candidate countries or the old EU member countries: $46 \%$ plan to move within the same town or city, compared to $47 \%$ among the new member countries and $52 \%$ in the candidate countries and also the old EU countries.

Prospective mobility differs quite strikingly from past mobility, however, when it comes to migrating across national borders. Whereas only a small fraction of Czech respondents lived in a foreign country in the past, almost 9\% would like to move to another European country and 6\% to a country outside of Europe. Similarly, $10 \%$ of nationals of the new member and candidate countries plan to move within Europe and 3-4\% intend to move overseas. ${ }^{11}$ These figures, however, should not be interpreted as a sign of massive future East-West flow from the candidate countries. Migration intentions can easily overestimate actual mobility. Note, in particular, that respondents in the old EU countries have similarly high intentions to move abroad: 8\% plan to move to another EU country and 7\% to a non-EU country.

11 The country-specific figures not reported here (available upon request) suggest that Bulgarians are particularly eager to move abroad, with $36 \%$ planning to move to Europe and $21 \%$ overseas. The least migrationprone country is Malta (3\% intending to move abroad and none overseas), followed, somewhat surprisingly, by Turkey (3\% and $2 \%$, respectively). 
It is instructive to consider also the motives for which people move. Table 2 reports the reasons for moving or intending to move. By far, the most important motivation is family considerations, followed by housing. The candidates and members are very similar in this respect. Importantly, economic motives (whether work or financial reasons) account for a relatively small fraction of past migrations: $14.8 \%$ of Czech respondents moved because of their work and $11 \%$ moved because of financial reasons. While it may appear low, the share of workrelated mobility is in fact the third highest among the candidate countries, and ranks high also among the old EU members. Economic considerations, however, are expected to play a more important role with respect to future migration decisions. Finally, and reassuringly, Czechs generally like their neighbors and do not often move because they dislike the people living near them.

Insert Table 2 about here.

Before moving on to quantitative analysis of migration patterns, it is instructive to discuss also evidence on Czechs' willingness to move. Willingness to move refers to the respondents' preparedness to move under specific, hypothetical, circumstances of interest. The average responses are summarized in Table 3. First, the respondents were asked to indicate their preparedness to move in case they were unemployed and moving would improve their prospect of finding a job. The interview questionnaire explicitly offered only two alternatives (stay or move); however, the interviewers were instructed to accept also it depends responses if offered spontaneously. ${ }^{12}$ The Czechs are not particularly eager to move even when faced with the prospect of remaining unemployed: only $29 \%$ indicated they would be prepared to move. Only 25\% are intent on staying, whereas most respondents (32\%) indicated it would depend on the job they would get if they moved. Czechs thus appear rather reluctant or hesitant to move compared to national of other candidate, new member or old EU countries. The next two willingness-tomove question address the respondents preparedness to migrate abroad: whether they would be to willing live in another European country (70\% of Czechs answer not at all willing or not much willing), and whether they intend to go to live and work in a current EU member country (89\% answer no, this being the third highest figure among the candidate countries, after Malta and Slovenia). 
Insert Table 3 about here.

In summary, the Czechs are among the least migration-prone Europeans. Those who do move are quite happy to move within their own country but not internationally. We may see more international migration in the future, nonetheless. While only a relatively small fraction of past migration was motivated by economic considerations, mobility motivated by work-related and/or financial reasons may become more important in the future.

An argument often brought up to explain the low and falling labor mobility in the Czech Republic is the inefficient nature of housing and credit markets, and large inter-regional differentials in housing and rental prices. Accordingly, people in depressed regions do not move for any from, or combination of, the following reasons: because they cannot afford to buy or rent housing in more prosperous regions, because a large part of the housing stock is publicly owned or otherwise regulated and therefore cannot be traded freely, and because banks are reluctant to provide long-term mortgage loans (and if they do, they may require excessive collateral backing). However, the evidence reported by Fidrmuc and Huber (2004b) suggests this argument can at best provide a partial explanation of the low mobility in the Czech Republic: they report the results of a survey (carried out in 1998) that asked respondents whether they would be prepared to move if they were unemployed and were offered both employment and housing in a distant municipality. The survey question was thus worded so as to remove the housing constraint from the respondents' decision - yet, 59\% answered they would not move and only $41 \%$ were prepared to consider moving.

\section{What Drives Migration?}

Blanchard and Katz (1992) in their analysis of regional labor-market dynamics find that labor mobility is the primary channel of regional adjustment in the wake of employment shocks in the United States. Decressin and Fatás (1995), in contrast, find that European employment shocks, for the most part, lead to lower labor-force participation rather than emigration of the surplus labor. For an economist, the capacity of labor mobility to facilitate regional adjustment is therefore one of the most interesting aspects of migration.

\footnotetext{
${ }^{12}$ The precise wording of this question, and the following two, is reproduced in the footnotes to Table 3.
} 
The descriptive analysis in the preceding section shows that: mobility is rather low in the Czech Republic despite sizeable regional disparities; much of it is churning flows; net migration is relatively modest; and the bulk of moves are motivated by non-economic motives such as family or housing considerations. In comparative perspective, Czechs are generally less mobile than nationals of other European countries, although the difference is not too dramatic. These findings suggest that migration is not very effective at facilitating regional adjustment. In this section, I pursue this question further.

The official migration statistics discussed above can be used to analyze the economic determinants of inter-regional migration. ${ }^{13}$ The data record gross and net migration at district (okres) level from 1992 to 1998, that is, gross population inflow and outflow and net inflow per district, without distinguishing the region of origin for the inflows and destination for the outflows. ${ }^{14}$ Migration rates, i.e. migration as a percentage of the district population, are related to labor-market conditions: unemployment rate, average wage, and population density (as a measure of congestion and/or urbanization). Because of possible endogeneity of local labormarket conditions with respect to migration, the unemployment rate and average wage are both lagged by one year. To remove the effect of wage inflation, average wages are divided by the respective year's national average wage (the resulting variable is denoted as the wage ratio). For migration to be effective at facilitating regional adjustment to shocks, the gross inflow should be positively related to the average wage and negatively related to the unemployment rate. The opposite should hold for the gross outflow. Correspondingly, the net immigration should be positively related to the average wage and negatively related to the unemployment rate. This kind of relationship would imply that, on average, people move from depressed regions, characterized by high unemployment and/or low incomes, to regions with more favorable conditions (unless, of course, high unemployment is compensated by high wages or vice versa). If such a relationship holds, migration will help equalize labor-market conditions across regions in the wake of employment shocks. Failure of migration to respond to regional labor-market

13 See Fidrmuc (2004) for a more in-depth comparative analysis of migration determinants in a number of accession-candidate and EU member countries, on which the discussion in this and the following two paragraphs is based.

${ }^{14}$ Data on district-to-district flows are also available, however, as the average district size is rather small, a large part of flows are either zeros or very low numbers, requiring more complicated econometric modeling (see Fidrmuc and Huber, 2004). For the sake of simplicity and tractability, I analyze here a reduced-form relationship 
conditions, on the other hand, would signify limited ability of regions to absorb adverse effects of idiosyncratic shocks, so that unemployment and wage differentials would persist in the long term.

The results of this analysis are presented in Table 4. The unemployment rate has the expected (negative) sign for both gross inflow and outflow, but only the coefficient for gross inflows is statistically significant. This implies that, as expected, regions stricken by high unemployment tend to receive fewer migrants, although, contrary to expectation, they do not seem to experience higher than average outflow of migrants. The average wage, in contrast, increases both gross immigration and emigration. Hence, the data reveal the expected pattern of migration only for the gross inflow but not for the gross outflow of migrants. People who decide to move may select their destinations with economic considerations on their minds, but economic factors do not seem equally important in inducing people to move out of depressed regions. Instead, it appears that the bulk of migration is in fact between relatively well-off districts rather than from depressed regions to those with favorable labor-market realizations.

Insert Table 4 about here.

The results obtained with net migration reveal a similar pattern: unemployment is negatively correlated with net immigration while wages apparently have no effect. Hence, the evidence is only partially consistent with migration effectively facilitating regional adjustment to employment shocks. Even more importantly, the response of net migration to regional labormarket conditions, although statistically significant in case of unemployment, is not economically significant. In particular, even large unemployment differentials give rise to only small population changes: the migration flow attributable to an unemployment-rate differential of 10 percentage points only amounts to $0.22 \%$ of the district's population, and a wage differential of $100 \%$ (i.e. change in the wage ratio of 1) only increases net immigration by $0.07 \%$ of the district's population. The speed of adjustment implied by these figures is extremely low: it would take years or decades to eliminate even modest labor-market disparities only through migration.

with overall inflows and outflows per districts. The analysis reported here is based only on data going through 1998 because of the change in regional structure in 1999 discussed in section 2. 
The regional analysis of migration can be complemented by, and contrasted with, a similar analysis based on individual data. To this end, I utilize the Eurobarometer survey data discussed extensively in the preceding section. Besides giving details on the respondents' past and prospective migration behavior, the surveys contain also a host of information about their socioeconomic characteristics. To analyze individual determinants of migration, I relate the responses to questions about past and prospective mobility and their willingness to move to the respondents' individual characteristics. In the light of the preceding discussion about migration and adjustment to employment shocks, it is of particular interest to see whether respondents are more likely to move when faced with adverse circumstances such as unemployment or low earnings. For such individuals, migration can potentially bring about a substantial improvement in their wellbeing. Therefore, one can expect that disadvantaged individuals will display higher mobility, especially prospective mobility and willingness to move, than the general population.

The results of logit regressions with past and prospective mobility are summarized in Table 5. For both types of mobility, I report regression estimates obtained with overall migration first and then those based on long-distance mobility (i.e. excluding moves within the same town or city), as short-distance moves are least likely to be motivated by economic considerations. With respect to finding evidence of economic motivation for migration, the results are disappointing: the respondents' individual characteristics play essentially no role as far in explaining past mobility. None of the variables is significant even at the $10 \%$ level in the regression with overall past mobility, and only two variables - history of past unemployment and living in a city - turn out significant in the regression with long-distance mobility. This pattern can be interpreted in two ways: either past mobility was uncorrelated with the migrants' individual characteristics, or it was correlated before migrating but the factors instigating the respondents to move were annulled by the act of moving (for example, this would be the case if it was mainly the unemployed who migrated and most of them found jobs after moving). It is noteworthy that individuals who were unemployed before are more likely to have migrated. Given that this pattern only obtains for the respondents with a history of unemployment but for not those currently unemployed, this is indeed consistent with the unemployed improving their wellbeing through migration.

A stronger result obtains for prospective mobility. Married respondents are less likely to intend to migrate, and migration intentions decline also with age (the pattern appears in fact U- 
shaped, albeit without the quadratic term being significant; the implied trough is at the age of 72 for overall mobility and 51 for long-distance mobility). Respondents with white-collar professional occupations, the self-employed and those with higher incomes are less likely to move (however, the last effect is only significant for the third income quartile and only for overall mobility): possibly because the relatively well-to-do respondents are contend with their current situation and have little incentive to move. Similarly, retirees are less mobile, not surprisingly, given that migration is not likely to improve their wellbeing much. Universityeducated individuals appear more mobile. Finally, as with past mobility, respondents who were unemployed before are more likely to move again in the future. In contrast to past mobility, it is the respondents with repetitive unemployment spells who appear more likely to move in the future rather than those with a single spell. It is possible that such respondents tend to see themselves as being more at risk of becoming unemployed again, or do not see their current situation as optimal and intend to improve on it further.

Insert Table 5 about here.

The results of the regression analysis of willingness to move (Table 6) are more interesting, given the nature of questions that the respondents were asked. The first question, addressing willingness to move if unemployed, offered the respondents three alternative responses (move, stay, and it depends. Therefore, this regression is estimated using the multinomial logit method, with the stay alternative being the base category. That means that the regression coefficients reflect the impact of the various variables on the probability of choosing one of the two remaining responses (move or it depends) rather than choosing the base category). The question about willingness to move abroad offers four possible responses indicating increasing willingness (not at all, not much, to some extent, and very much) and is estimated as an ordered logit. The last question, willingness to move to the $\mathrm{EU}$, is estimated using the logit method.

The determinants of being prepared to move if unemployed and being ambivalent about it are very similar with each other, and also do not differ much from willingness to move abroad. In contrast, the regression results for willingness to move to the EU are disappointing, with most variables below conventional significance levels; this may be due to the fact that less than $11 \%$ of Czech respondents answered this question affirmatively. As with prospective mobility, being married reduces willingness to move if unemployed. Women are more likely to stay. Willingness 
to move falls with age in a U-shaped pattern, leveling off around the age of 56-57. Gender, marital status and age do not affect willingness to move abroad but having children does present a barrier to international mobility. Respondents in white-collar employment and the selfemployed are more willing to move if unemployed and to move abroad; those with university education or still in university are more likely to move abroad. Interestingly, individuals who are currently unemployed are more willing to move abroad but do not display similarly higher propensity to move in response to unemployment. Finally, urban dwellers are more willing to move both if unemployed and abroad.

Insert Table 6 about here.

Finally, as I argued above, individuals who experience economic hardship should face a greater incentive to move. The regressions presented in Tables 5 and 6 indicate that unemployment, either in the past or at present, seems associated with greater mobility although the effect is not highly consistent across the different models estimated. To gain a deeper insight into these issues, I replaced household income by two alternative measures of subjective wellbeing - an indication whether the household income is sufficient to meet its needs, and respondent's assessment of the household's financial situation as very poor/poor, getting along, comfortable, or rich/very rich. The results (which are available upon request) are mixed. On the one hand, while self-reported financial situation does not have any bearing on prospective mobility, respondents who perceive their household as just getting along, and poor or very poor are less willing to move if unemployed and also less willing to move abroad (none of the categories is significant with respect to moving to the EU). Thus, it seems that respondents in financial hardship are either discouraged from moving or perhaps are unable to move because they are liquidity-constrained: that is, unable to bear the cost of moving even if migration would help them to improve their wellbeing. On the other hand, a different pattern obtains with the income-relative-to-household-needs variable: respondents who feel their household income is sufficient or more than sufficient to meet their needs are less likely to be ambivalent about moving when unemployed (the impact on being prepared to move unconditionally is insignificant), and less likely to move either abroad or to the EU. 


\section{Conclusions}

People move for various reasons: because of family considerations, in an effort to improve their housing situation, or because they prefer to live in a specific region, city or town. An important aspect of migration, however, is that it is often driven by economic factors such as finding employment or getting a higher wage. In this way, migration is a crucial element of labor-market adjustment to idiosyncratic employment shocks. When the labor force is highly mobile, the effects of regional employment shocks are quickly evened out by migration flows: workers move from depressed regions to prosperous ones, until inter-regional differentials in unemployment and earnings are all but driven away.

In this paper, I analyze this economic aspect of migration. Using official statistics on interregional migration, I show that migration in the Czech Republic is low. Even more importantly, migration has been falling throughout most of the transition period, even as inter-regional disparities in labor-market conditions have increased. This picture is confirmed also by crosscountry survey data on past and prospective mobility, willingness to move in search of a job if unemployed, and willingness to live abroad. Within Europe, Czechs rank among the most reluctant migrants and generally prefer to stay where they are.

Not only is migration low in the Czech Republic, it also does not appear very effective in facilitating labor-market adjustment. According to my econometric analysis of inter-regional mobility, the net migration flow that can be expected to emanate from sizeable inter-regional differentials in unemployment and wages is too small to effectively eliminate these differentials. Migration does facilitate reallocation of labor in the wake of employment shocks, but the speed of this adjustment is very slow. The analysis with individual data delivers similar findings: economic factors play little role in explaining migration, especially past migration. There are some indications, nonetheless, that economic considerations may play a more important role for prospective mobility and for willingness to move.

The typical Czech prospective or potential migrant - both with respect to internal and international migration - is a young person, more often a male than a female, who lives in an urban region, has attained university education (or is still a student) and is a highly skilled whitecollar worker or self-employed. ${ }^{15}$ In other words, the prospective or potential migrants generally

\footnotetext{
${ }^{15}$ Klailová (2004) arrives at similar findings in the context of potential migration of Czechs to the EU in the wake of the Czech Republic's accession to the EU.
} 
have favorable human-capital characteristics and are relatively well-off. Importantly, migration does not seem to offer a viable path to economic improvement for those who find themselves in economic difficulties because they are unemployed and/or cannot make ends meet financially.

These findings have a number of important implications. First, migration in the Czech Republic remains largely a social and demographic phenomenon rather than an economic one. Hence, the potential of migration to facilitate labor-market adjustment is limited and therefore other tools for mitigating adverse shocks (including autonomous fiscal and monetary policy) will remain relatively important in the years to come. Second, the segment of the labor force that is mobile mainly comprises workers with favorable socio-economic characteristics. This may be because of barriers posed to labor mobility by the inefficiencies of the Czech housing market, or because less the well-off potential migrants are prevented from moving by liquidity and/or credit-market constraints. If the latter is the case, a continued economic recovery in the Czech Republic should increase the mobility of labor - both internally and internationally. Finally, inasmuch as Czech Republic's accession to the EU results in an outflow of labor to the 'old' EU member countries, the migrants are likely to be relatively highly skilled (see Klailová, 2004, for a more extensive discussion). The experience of other countries (see Friedberg, 2000, and Eckstein and Weiss, 1998), however, suggests that immigrants from East European countries tend to suffer from substantial occupational downgrading in the first few years after immigration. Hence, Czech migrants, though relatively skilled and educated, may well end up taking up low skilled jobs. If this is indeed the case, EU enlargement will translate into a brain drain for the Czech Republic and the other new member countries, without necessarily implying a corresponding brain gain for the old member countries. ${ }^{16}$

\footnotetext{
${ }^{16}$ Indeed, the experience of the UK (one of only three 'old' EU member country to allow unrestricted mobility of labor from the new members) suggests that most accession countries' migrants (131 thousand such migrants registered for employment in the UK between May and December 2004, including nearly 9 thousand Czechs) indeed take up relatively low-skilled occupations in hospitality and catering, agriculture, manufacturing and sales (see Home Office, 2005).
} 


\section{References}

Babetskii, I., L. Boone and M. Maurel (2004), "Exchange Rate Regimes and Shocks Aymmetry: The Case of the Accession Countries,” Journal of Comparative Economics 32 (2), 212-229.

Blanchard, Olivier Jean, and Katz, Lawrence F., "Regional Evolutions,” Brookings Papers on Economic Activity 1: 1-61, 1992.

Boeri, T., and H. Brücker (2000), The Impact of Eastern Enlargement on Employment and Labor Markets in the EU Member States, Report prepared for the DG Employment and Social Affairs, Berlin and Milan: mimeo.

Chand, S.K., and M. Paldam (2005), Some Economics of Immigration from an LDC to a DC: With Special Emphasis on the Case of a Nordic Welfare State, in: Dennis Snower (ed.), Labor Mobility and the World Economy, Berlin, Heidelberg: Springer, forthcoming.

Cohen, S., and D. Paserman (2004), The Dynamic Impact of Immigration on Natives' Labor Market Outcomes: Evidence from Israel, CEPR Discussion Paper No. 4640, Centre for Economic Policy Research, London.

Decressin, Jörg W., and Fatas, Antonio, “Regional labor market dynamics in Europe.” European Economic Review 39, 9: 1627-1655, December 1995.

Eckstein, Z. and Weiss, Y. (1998), The absorption of highly-skilled immigrants: Israel, 1990-95, CEPR Working Paper No. 1853, Centre for Economic Policy Research, London.

Fidrmuc, Jan (2004), "Migration and Regional Adjustment to Asymmetric Shocks in Transition Economies,” Journal of Comparative Economics 32 (2), 230-247.

Fidrmuc, Jan (2004a) and P. Huber, Where Have All the Migrants Gone? Reconciling Falling Migration Rates with Rising Regional Disparities during Transition, Université Libre de Bruxelles and WIFO, mimeo.

Fidrmuc, Jan (2004b) and P. Huber, Regional and Individual Determinants of the Willingness to Migrate in the Czech Republic, Université Libre de Bruxelles and WIFO, mimeo.

Fidrmuc, Jarko, and I. Korhonen (2003), "Similarity of Supply and Demand Shocks between the Euro Area and the CEECs,” Economic System 27 (3), 313-334.

Fidrmuc, Jarko, and I. Korhonen (2004), Meta-analysis of Business Cycle Correlations between the Euro-area and the CEECs: What Do We Know? And Who Cares? Oesterreichische Nationalbank and Bank of Finland, mimeo.

Friedberg, R.M. (2000). "You can’t take it with you? Immigrant assimilation and the portability of human capital,” Journal of Labor Economics, 18 (2), pp. 221-251.

Friedberg, R.M. and J. Hunt (1995), “The Impact of Immigrants on Host Country Wages, Employment and Growth.” Journal of Economic Perspectives 9 (2), 23-44.

Home Office (2005). Accession Monitoring Report: May - December 2004. Joint on-line report of the Home Office, the Department for Work and Pensions, the Inland Revenue Office, and the Office of the Deputy Prime Minister, 22 February 2005, available at http://www.ind.homeoffice.gov.uk/ind/en/home/0/reports/accession monitoring.Maincontent.0007.file .tmp/Final\%20Feb\%20accession\%20report.pdf. 
Horvath, J. and A. Rátfai (2004), "Supply and Demand Shocks in Accession Countries to the Economic and Monetary Union, Journal of Comparative Economics 32 (2), 202-211.

Huber, P. (2004), “Intra-national labor market adjustment in the candidate countries,” Journal of Comparative Economics 32 (2), 248-264.

Klailová, Š. (2004), Potential Labor Migration in the Wake of the EU Enlargement: Who Is About to Make the Move? With Focus on the Czech Republic, M.A. Dissertation, Universiteit Antwerpen and University of Economics Prague, mimeo.

Schuendeln, M. (2004), Are Immigrants More Mobile than Natives? Evidence from Germany, paper presented at the conference on "Advanced Perspectives on Migration and Mobility," ZEI, University of Bonn, September 2004.

Sinn, H.-W. (2004), Migration, Social Standard and Replacement Incomes: How to Protect Lowincome workers in the Industrialized Countries against the Forces of Globalization and Market Integration, CESIfo Working Paper No. 1265, Munich.

Sinn, H.-W., and M. Werding (2001), "Immigration Following EU Eastern Enlargement," CESifo Forum 2 (2), 40-47. 
Figure 1 Inter-regional Migration in the Czech Republic: 1992-2000

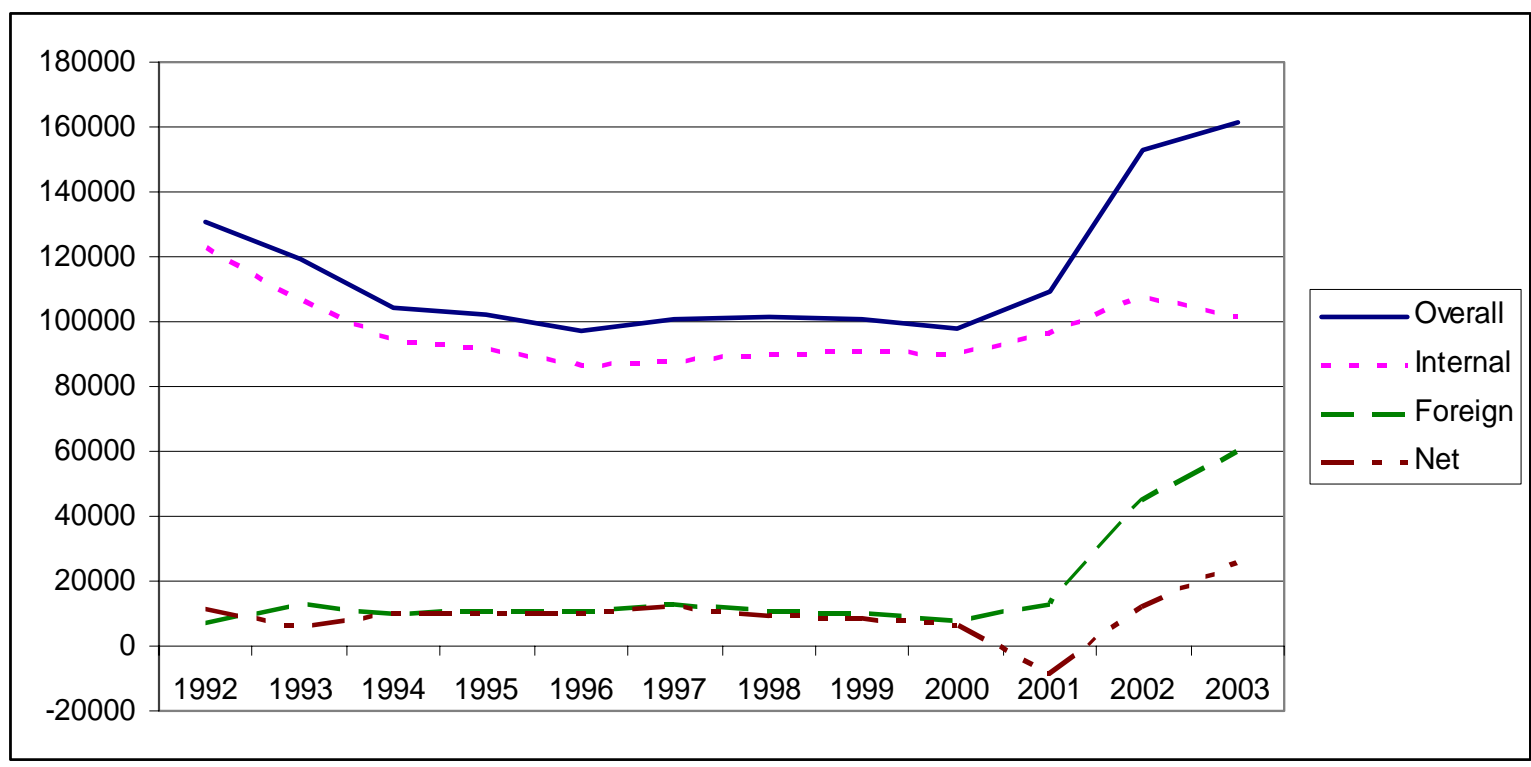

Notes: Figures based on the Czech population registry, including both Czech nationals, foreigners with permanent residency rights in the Czech Republic, and, as of 2001, also foreigners with long-term residency rights (one year or longer). Overall migration is the total number of arrivals, whether from within Czech Republic or abroad. Internal migration is arrivals from within Czech Republic, foreign migration is arrivals from abroad. Net migration is the net immigration to the Czech Republic. 
Table 1 Frequency of Past and Prospective Mobility

\begin{tabular}{|c|c|c|c|c|c|c|c|}
\hline \multicolumn{2}{|c|}{ Moved in the last ten years } & $\begin{array}{l}\text { How } \\
\text { many } \\
\text { times? }\end{array}$ & $\begin{array}{l}\text { Within } \\
\text { town/city }\end{array}$ & $\begin{array}{l}\text { Within } \\
\text { region }\end{array}$ & $\begin{array}{l}\text { Within } \\
\text { country }\end{array}$ & $\begin{array}{l}\text { Within } \\
\text { Europe } \\
\text { (EU) }\end{array}$ & $\begin{array}{l}\text { Outside } \\
\text { Europe } \\
\text { (EU) }\end{array}$ \\
\hline Czech Rep. & $20.3 \%$ & 1.26 & $54.2 \%$ & $35.0 \%$ & $15.3 \%$ & $1.0 \%$ & $1.5 \%$ \\
\hline AC10 & $24.6 \%$ & 1.57 & $65.1 \%$ & $30.4 \%$ & $13.9 \%$ & $2.8 \%$ & $1.1 \%$ \\
\hline AC13 & $29.0 \%$ & 1.78 & $67.0 \%$ & $28.5 \%$ & $14.5 \%$ & $1.7 \%$ & $0.7 \%$ \\
\hline EU15 & $37.5 \%$ & 1.80 & $67.3 \%$ & $36.0 \%$ & $20.2 \%$ & $4.0 \%$ & $4.2 \%$ \\
\hline \multicolumn{3}{|c|}{ Intends to move within 5 years } & $\begin{array}{l}\text { Within } \\
\text { town/city }\end{array}$ & $\begin{array}{l}\text { Within } \\
\text { region }\end{array}$ & $\begin{array}{l}\text { Within } \\
\text { country }\end{array}$ & $\begin{array}{l}\text { Within } \\
\text { Europe } \\
\text { (EU) }\end{array}$ & $\begin{array}{l}\text { Outside } \\
\text { Europe } \\
\text { (EU) }\end{array}$ \\
\hline Czech Rep. & $13.0 \%$ & & $46.1 \%$ & $27.3 \%$ & $21.1 \%$ & $8.6 \%$ & $6.3 \%$ \\
\hline AC10 & $15.6 \%$ & & $46.7 \%$ & $27.6 \%$ & $20.0 \%$ & $10.2 \%$ & $3.4 \%$ \\
\hline AC13 & $19.2 \%$ & & $51.9 \%$ & $24.7 \%$ & $21.1 \%$ & $9.8 \%$ & $3.7 \%$ \\
\hline EU15 & $18.4 \%$ & & $51.5 \%$ & $30.2 \%$ & $25.5 \%$ & $7.5 \%$ & $6.8 \%$ \\
\hline
\end{tabular}

Notes: The first column reports the percentage of respondents moved at least once during the past ten years (upper panel) and who intend to move during the next five years (lower panel). The second column reports how many times those respondents have moved on average. The subsequent columns report on the distance of the move. AC10 stands for the average over the ten countries that became EU members in May 2004. AC13 and EU15 refer to the 13 countries that were candidates for EU membership and the 15 countries that were EU members before May 2004, respectively. The averages for AC10, AC13 and EU15 are weighted by population.

Sources: Candidate Countries Eurobarometer Spring 2002 and Eurobarometer 542/2001.

Table 2 Reasons for Moving: Past and Prospective Mobility

\begin{tabular}{l|rrrrrr}
\hline $\begin{array}{l}\text { Reasons for having } \\
\text { moved in the past }\end{array}$ & $\begin{array}{c}\text { Neighbors, } \\
\text { people }\end{array}$ & House & $\begin{array}{l}\text { Family } \\
\text { reasons }\end{array}$ & \multicolumn{1}{c}{$\begin{array}{l}\text { Financial } \\
\text { reasons }\end{array}$} & Work & Other \\
\hline Czech Rep. & $3.4 \%$ & $26.6 \%$ & $63.1 \%$ & $11.3 \%$ & $14.8 \%$ & $9.9 \%$ \\
AC10 & $3.2 \%$ & $24.8 \%$ & $57.2 \%$ & $14.0 \%$ & $12.6 \%$ & $13.1 \%$ \\
AC13 & $5.4 \%$ & $25.2 \%$ & $43.8 \%$ & $24.0 \%$ & $18.0 \%$ & $11.7 \%$ \\
EU15 & $3.2 \%$ & $17.6 \%$ & $54.1 \%$ & $8.6 \%$ & $15.0 \%$ & $15.8 \%$ \\
\hline Reasons for & Neighbors, & House & Family & Financial & Work & Other \\
planning to move & people & & & reasons & & \\
\hline Czech Rep. & $4.7 \%$ & $36.7 \%$ & $67.2 \%$ & $21.9 \%$ & $27.3 \%$ & $16.4 \%$ \\
AC10 & $7.4 \%$ & $29.4 \%$ & $47.0 \%$ & $25.4 \%$ & $29.1 \%$ & $13.0 \%$ \\
AC13 & $9.5 \%$ & $27.5 \%$ & $34.7 \%$ & $36.9 \%$ & $29.4 \%$ & $11.0 \%$ \\
EU15 & $5.1 \%$ & $15.3 \%$ & $47.0 \%$ & $10.1 \%$ & $27.7 \%$ & $15.8 \%$ \\
\hline
\end{tabular}

The respondents were allowed to list multiple reasons. AC13 and EU15 refer to the 13 countries that were candidates for EU membership and the 15 countries that were EU members before May 2004, respectively. The averages for AC10, AC13 and EU15 are weighted by population.

Sources: Candidate Countries Eurobarometer Spring 2002 and Eurobarometer 542/2001. 
Table 3 Willingness to Move (WTM)

\begin{tabular}{l|rrrr}
\hline WTM if unemployed & Would stay & Would move & \multicolumn{1}{c}{ It depends } & \\
\hline Czech Rep. & $24.9 \%$ & $29.4 \%$ & $31.9 \%$ & \\
AC10 & $35.3 \%$ & $37.7 \%$ & $18.1 \%$ & \\
AC13 & $36.0 \%$ & $45.4 \%$ & $11.4 \%$ & \\
EU15 & $34.0 \%$ & $37.9 \%$ & $16.1 \%$ & \\
\hline WTM aboad & Not at all & Not much & To some extent & Very much \\
\hline Czech Rep. & $50.3 \%$ & $19.4 \%$ & $25.9 \%$ & $7.5 \%$ \\
AC10 & $48.6 \%$ & $17.7 \%$ & $26.2 \%$ & $8.7 \%$ \\
AC13 & $46.4 \%$ & $17.7 \%$ & $22.4 \%$ & \\
EU15 & $45.8 \%$ & $21.6 \%$ & $20.5 \%$ & \\
\hline WTM to the EU & No & Yes & \\
\hline Czech Rep. & $89.4 \%$ & $10.6 \%$ & & \\
AC10 & $85.7 \%$ & $14.3 \%$ & & \\
AC13 & $76.5 \%$ & $23.5 \%$ & & \\
EU15 & No comparable question available. & & \\
\hline
\end{tabular}

Notes: AC10 stands for the ten countries that became EU members in May 2004. AC13 refers to the 13 countries that were candidates for EU membership before May 2004. The averages for AC10 and AC13 are weighted by population. The first panel reports responses to the following question: Please imagine that you are unemployed. Which of the two statements comes closest to your opinion?, with the following alternative answers: I would rather remain in the same region where I live even if I don't find a job, or I would rather move to another region to find a job. The response It depends on the job I could get elsewhere was not read to the respondents but was accepted if offered spontaneously. The second panel presents responses to How willing would you be to live in another European country where the language is different from your mother tongue?, with possible responses not at all, not much, to some extent, and very much. The question asked in the $15 \mathrm{EU}$ countries replaced another European country with another country of the European Union. The third panel reports responses to Do you intend to go to live and work - for a few months or for several years - in a current European Union country in the next five years? Source: Candidate Countries Eurobarometer, Spring 2002. 
Table 4 Determinants of Inter-regional Migration, 1992 to 1998

\begin{tabular}{|c|c|c|c|c|c|c|}
\hline \multirow[b]{2}{*}{ Unemployment Rate (lagged) } & \multicolumn{2}{|c|}{$\begin{array}{l}\text { Inflows } \\
(1) \\
\end{array}$} & \multicolumn{2}{|c|}{$\begin{array}{l}\text { Outflows } \\
(2)\end{array}$} & \multicolumn{2}{|c|}{$\begin{array}{l}\text { Net Inflows } \\
(3) \\
\end{array}$} \\
\hline & -0.017 & $(2.90)$ & 0.002 & $(0.52)$ & -0.022 & (2.97) \\
\hline Wage Ratio (lagged) & 0.462 & $(2.71)$ & 0.469 & $(4.16)$ & 0.069 & $(0.32)$ \\
\hline Population Density (log) & -3.864 & $(5.43)$ & -0.061 & $(2.18)$ & -4.096 & $(4.65)$ \\
\hline Dummy 1993 & -0.188 & $(9.05)$ & -0.134 & $(9.45)$ & -0.058 & $(2.25)$ \\
\hline Dummy 1994 & -0.267 & (13.69) & -0.255 & (19.04) & -0.011 & $(0.46)$ \\
\hline Dummy 1995 & -0.288 & $(13.23)$ & -0.281 & $(18.87)$ & -0.006 & $(0.23)$ \\
\hline Dummy 1996 & -0.343 & (15.53) & -0.347 & $(23.01)$ & 0.004 & $(0.14)$ \\
\hline Dummy 1997 & -0.305 & $(14.66)$ & -0.343 & $(24.03)$ & 0.039 & $(1.50)$ \\
\hline Dummy 1998 & -0.227 & $(10.18)$ & -0.320 & $(21.10)$ & 0.101 & (3.65) \\
\hline Constant & 19.482 & (5.67) & 1.047 & $(6.68)$ & 19.781 & $(4.64)$ \\
\hline District Fixed Effects & Yes & & Yes & & Yes & \\
\hline District Random Effects & No & & No & & No & \\
\hline $\mathrm{R}^{2}$ (within) & 0.567 & & 0.780 & & 0.124 & \\
\hline $\mathrm{R}^{2}$ (between) & 0.047 & & 0.125 & & 0.056 & \\
\hline $\mathrm{R}^{2}$ (overall) & 0.042 & & 0.325 & & 0.031 & \\
\hline Breusch-Pagan test (p-value) & 1022.09 & $(0.00)$ & 1071.07 & $(0.00)$ & 290.12 & $(0.00)$ \\
\hline Hausman test stat. (p-value) & 48.82 & $(0.00)$ & 15.90 & $(0.07)$ & 21.36 & $(0.01)$ \\
\hline
\end{tabular}

Notes: The dependent variables are the gross inflow and outflow rates and net inflow rate (based on internal migration only) as a percentage of the region's end-year population, respectively. T-statistics are reported in parentheses. The number of observations is 518 (74 districts over 7 years, the districts of Bruntal, Jesenik and Sumperk are excluded because of changes in their territorial structure as of 1996). The unemployment rate and the wage ratio are lagged by one year. 
Table 5 Determinants of Past and Prospective Migration Behavior

\begin{tabular}{|c|c|c|c|c|c|c|c|c|}
\hline & Past mobility & & Past mobility, & listance & Future mobili & & Future mobilit & distance \\
\hline Female & 0.105 & $(0.226)$ & 0.189 & $(0.317)$ & 0.177 & $(0.364)$ & -0.072 & $(0.500)$ \\
\hline Married & 0.126 & $(0.306)$ & 0.116 & $(0.397)$ & $-1.115^{* * *}$ & $(0.361)$ & $-1.617 * * *$ & $(0.495)$ \\
\hline Age & -0.092 & $(0.060)$ & -0.044 & $(0.084)$ & $-0.155^{*}$ & $(0.082)$ & $-0.199 * *$ & $(0.098)$ \\
\hline Age squared & 0.0001 & $(0.0007)$ & -0.0004 & $(0.0010)$ & 0.0011 & $(0.0010)$ & 0.0019 & $(0.0012)$ \\
\hline Children & 0.132 & $(0.141)$ & -0.106 & $(0.196)$ & -0.026 & $(0.248)$ & -0.223 & $(0.319)$ \\
\hline HH Size & -0.141 & $(0.127)$ & -0.078 & $(0.167)$ & -0.260 & $(0.201)$ & -0.157 & $(0.246)$ \\
\hline Secondary & -0.305 & $(0.471)$ & 0.093 & $(0.723)$ & 1.372 & (1.079) & 0.636 & $(1.035)$ \\
\hline University & 0.604 & $(0.517)$ & 0.647 & $(0.790)$ & $1.981 *$ & (1.135) & 1.630 & (1.169) \\
\hline Student & -1.074 & $(0.769)$ & -0.970 & (1.151) & 0.939 & (1.396) & 0.465 & (1.389) \\
\hline Self-employed & 0.304 & $(0.429)$ & 0.469 & $(0.601)$ & $-1.919 *$ & (1.081) & Dropped & \\
\hline White collar & 0.171 & $(0.312)$ & 0.093 & $(0.434)$ & $-0.954 * *$ & $(0.467)$ & -0.566 & $(0.601)$ \\
\hline House person & 0.541 & $(0.532)$ & 0.137 & $(0.637)$ & -1.070 & $(0.968)$ & -1.112 & $(1.228)$ \\
\hline Unemployed & 0.695 & $(0.523)$ & -0.506 & $(0.765)$ & -0.876 & $(0.776)$ & -0.040 & $(0.927)$ \\
\hline Retiree & 0.694 & $(0.514)$ & 1.096 & $(0.808)$ & $-3.395 * *$ & $(1.527)$ & Dropped & \\
\hline UE History: 1 & 0.485 & $(0.332)$ & $0.919 * *$ & $(0.414)$ & -0.078 & $(0.423)$ & -0.110 & $(0.559)$ \\
\hline UE History: 2+ & 0.679 & $(0.430)$ & 0.814 & $(0.527)$ & $1.332 * *$ & $(0.649)$ & $1.704^{* *}$ & $(0.862)$ \\
\hline HH Income 2nd Quartile & 0.036 & $(0.340)$ & -0.275 & $(0.474)$ & -0.476 & $(0.486)$ & 0.143 & $(0.613)$ \\
\hline HH Income 3rd Quartile & -0.429 & $(0.375)$ & -0.257 & $(0.487)$ & $-1.462 * * *$ & (0.578) & -0.984 & $(0.824)$ \\
\hline HH Income 4th Quartile & -0.369 & $(0.384)$ & -0.016 & $(0.461)$ & -0.231 & $(0.592)$ & 0.387 & $(0.730)$ \\
\hline Small/Medium town & -0.062 & $(0.265)$ & -0.981 & $(0.385)$ & $0.882 * *$ & $(0.443)$ & -0.227 & $(0.534)$ \\
\hline City & 0.356 & $(0.277)$ & $-0.523 * * *$ & $(0.363)$ & $0.997 * *$ & $(0.512)$ & -0.626 & $(0.803)$ \\
\hline Constant & 2.401 & $(1.461)$ & 0.420 & $(2.058)$ & 2.683 & $(2.260)$ & 3.184 & $(2.261)$ \\
\hline Log likelihood & -285.794 & & -171.356 & & -115.691 & & -70.900 & \\
\hline Pseudo $\mathrm{R}^{2}$ & 0.170 & & 0.150 & & 0.356 & & 0.305 & \\
\hline Wald $\chi^{2}$ & $87.590 * * *$ & & $52.260 * * *$ & & $94.550 * * *$ & & $51.240 * * *$ & \\
\hline No. of observations & 642 & & 642 & & 558 & & 346 & \\
\hline
\end{tabular}

Notes: Estimated as a logit regression, with robust standard errors in parentheses. Significance levels are denoted as *** $1 \%$, ** $5 \%$, and * $10 \%$. Past mobility takes value of 1 if the respondent reports to have moved once or more often during the past ten years. Long-distance past mobility is constructed analogously but excludes those respondents who have moved within the same city, town or village. Future mobility takes value of 1 if the respondents reports to intend to move during the next five years. Future long-distance mobility excludes those respondents who intend to move within the same city, town or village. Variables indicated as 'dropped' were eliminated from the regression because they do not vary with the outcome. The omitted categories are: male, not married or not cohabiting, primary education, manual worker, no past unemployment experience, rich/very comfortable/comfortable well-being, and village/rural area. 
Table 6 Determinants of Willingness to Move

\begin{tabular}{|c|c|c|c|c|c|c|c|c|}
\hline \multirow{3}{*}{\begin{tabular}{|l|} 
\\
Female \\
\end{tabular}} & \multicolumn{4}{|c|}{ Willing to move if unemployed } & \multirow{2}{*}{\multicolumn{2}{|c|}{ Willing to move abroad }} & \multirow{2}{*}{\multicolumn{2}{|c|}{$\begin{array}{l}\text { Intends to live and work in } \\
\text { the } E U\end{array}$}} \\
\hline & \multicolumn{2}{|c|}{ Would move to find job } & \multicolumn{2}{|c|}{ Depends on the job } & & & & \\
\hline & $-0.758 * * *$ & $(0.245)$ & $-0.479 * *$ & $(0.244)$ & -0.232 & $(0.179)$ & 0.401 & $(0.464)$ \\
\hline Married & $-1.058 * * *$ & $(0.317)$ & $-1.029 * * *$ & $(0.331)$ & -0.057 & $(0.219)$ & 0.320 & $(0.586)$ \\
\hline Age & $-0.159 * * *$ & $(0.060)$ & $-0.159 * * *$ & $(0.061)$ & -0.065 & $(0.046)$ & 0.079 & $(0.178)$ \\
\hline Age squared & $0.0014^{* *}$ & $(0.0006)$ & $0.0014^{* *}$ & $(0.0007)$ & 0.0003 & $(0.0005)$ & -0.0021 & $(0.0025)$ \\
\hline Children & 0.081 & $(0.144)$ & 0.104 & $(0.136)$ & $-0.257 * *$ & $(0.107)$ & $-0.966 * * *$ & $(0.290)$ \\
\hline HH Size & 0.045 & $(0.136)$ & 0.027 & $(0.131)$ & -0.069 & $(0.106)$ & 0.049 & $(0.226)$ \\
\hline Secondary & -0.054 & $(0.437)$ & -0.158 & $(0.433)$ & 0.580 & $(0.407)$ & $-1.890 * *$ & $(0.950)$ \\
\hline University & 0.597 & $(0.512)$ & 0.168 & $(0.512)$ & $1.530 * * *$ & $(0.445)$ & -1.129 & $(1.222)$ \\
\hline Student & -0.627 & $(0.979)$ & -0.567 & $(0.959)$ & $1.978 * * *$ & $(0.638)$ & 0.520 & $(1.291)$ \\
\hline Self-employed & $1.245^{* *}$ & $(0.511)$ & $1.727 * * *$ & $(0.489)$ & $0.643^{* *}$ & $(0.321)$ & 1.058 & $(0.754)$ \\
\hline White collar & $0.772 * *$ & $(0.328)$ & $1.015^{* * *}$ & $(0.340)$ & $0.588^{* *}$ & $(0.262)$ & 0.327 & $(0.672)$ \\
\hline House person & -0.305 & $(0.755)$ & 0.564 & $(0.596)$ & 0.528 & $(0.397)$ & dropped & \\
\hline Unemployed & -0.861 & $(0.562)$ & -0.715 & $(0.714)$ & $0.842 *$ & $(0.442)$ & -0.211 & $(0.917)$ \\
\hline Retiree & 0.279 & $(0.495)$ & 0.242 & $(0.488)$ & -0.108 & $(0.442)$ & 0.310 & (1.407) \\
\hline UE History: 1 & 0.644 & $(0.434)$ & 0.260 & $(0.429)$ & -0.108 & $(0.254)$ & -0.108 & (0.629) \\
\hline UE History: 2+ & -0.230 & $(0.442)$ & -0.557 & $(0.521)$ & 0.124 & $(0.299)$ & 0.713 & $(0.953)$ \\
\hline HH Income 2nd Quartile & -0.109 & $(0.346)$ & -0.040 & $(0.356)$ & 0.505 & $(0.291)$ & 0.106 & $(0.908)$ \\
\hline HH Income 3rd Quartile & 0.306 & $(0.407)$ & 0.241 & $(0.408)$ & $0.533^{*}$ & $(0.319)$ & -0.962 & $(0.923)$ \\
\hline HH Income 4th Quartile & $-0.728^{*}$ & $(0.443)$ & -0.006 & $(0.436)$ & 0.329 & $(0.329)$ & -1.173 & (1.063) \\
\hline Small/Medium town & $0.666 * * *$ & $(0.265)$ & $0.530 * *$ & $(0.266)$ & 0.198 & $(0.203)$ & 0.020 & $(0.498)$ \\
\hline City & $1.060 * * *$ & $(0.312)$ & $0.881^{* * *}$ & $(0.313)$ & $0.534^{* *}$ & $(0.239)$ & -0.165 & $(0.687)$ \\
\hline Constant & $4.135^{* * *}$ & $(1.525)$ & $3.980 * * *$ & $(1.525)$ & & & -0.312 & $(2.941)$ \\
\hline Log likelihood & -557.287 & & & & -585.957 & & -84.298 & \\
\hline Pseudo $\mathrm{R}^{2}$ & 0.089 & & & & 0.161 & & 0.373 & \\
\hline Wald $\chi^{2}$ & $93.840^{* * *}$ & & & & $184.760^{* * *}$ & & $68.600^{* * *}$ & \\
\hline No. of observations & 557 & & & & 627 & & 573 & \\
\hline
\end{tabular}

Notes: The first regression (WTM if unemployed) is estimated as a multinomial logit, with the "would rather not move" response as the base category. The second regression (WTM abroad) is estimated as an ordered logit. The third regression (WTM to the EU) is estimated as an ordinary logit. Robust standard errors are in parentheses. Significance levels are denoted as $* * * 1 \%, * * 5 \%$, and $* 10 \%$.Variables indicated as 'dropped' were eliminated from the regression because they do not vary with the outcome. The omitted categories are: male, not married or not cohabiting, primary education, manual worker, no past unemployment experience, rich/very comfortable/comfortable well-being, and village/rural area. 


\section{DAVIDSON INSTITUTE WORKING PAPER SERIES - Most Recent Papers}

The entire Working Paper Series may be downloaded free of charge at: www.wdi.bus.umich.edu

CURRENT AS OF 4/29/05

\begin{tabular}{|c|c|c|}
\hline Publication & Authors & Date \\
\hline $\begin{array}{l}\text { No. 768: Testing for inflation convergence between the Euro Zone } \\
\text { and its CEE partners }\end{array}$ & Imed Drine and Christophe Rault & Apr. 2005 \\
\hline $\begin{array}{l}\text { No. 767: Labor Mobility during Transition: Evidence from the Czech } \\
\text { Republic }\end{array}$ & Jan Fidrmuc & Apr. 2005 \\
\hline $\begin{array}{l}\text { No. 766: Formation of social capital in Central and Eastern Europe: } \\
\text { Understanding the gap vis-à-vis developed countries }\end{array}$ & Jan Fidrmuc and Klarita Gërxhani & Apr. 2005 \\
\hline $\begin{array}{l}\text { No. 765: Do Regional Integration Agreements Increase Business-Cycle } \\
\text { Convergence? Evidence From APEC and NAFTA }\end{array}$ & $\begin{array}{l}\text { Viviana Fernandez and Ali M. } \\
\text { Kutan }\end{array}$ & Apr. 2005 \\
\hline $\begin{array}{l}\text { No. 764: State Regulations, Job Search and Wage Bargaining: A Study } \\
\text { in the Economics of the Informal Sector }\end{array}$ & Maxim Bouev & Apr. 2005 \\
\hline $\begin{array}{l}\text { No. 763: The Feldstein-Horioka Puzzle Revisited: An “European- } \\
\text { Regional” Perspective }\end{array}$ & $\begin{array}{l}\text { Jérôme Hericourt and Mathilde } \\
\text { Maurel }\end{array}$ & Apr. 2005 \\
\hline $\begin{array}{l}\text { No. 762: Transatlantic Differences in Labour Markets Changes in Wage } \\
\text { and Non-Employment Structures in the 1980s and the 1990s }\end{array}$ & Patrick A. Puhani & Mar. 2005 \\
\hline $\begin{array}{l}\text { No. 761: Resolution, Recovery and Survival: The Evolution of Payment } \\
\text { Disputes in Post-Socialist Europe }\end{array}$ & Willi & Mar. 2005 \\
\hline $\begin{array}{l}\text { No. 760: Official Foreign Exchange Interventions in the Czech } \\
\text { Republic: Did They Matter? }\end{array}$ & Balázs Ége & Mar. 2005 \\
\hline $\begin{array}{l}\text { No. 759: Assessing Market Expectations on Exchange Rates and } \\
\text { Inflation: A Pilot Forecasting System for Bulgaria }\end{array}$ & $\begin{array}{l}\text { Michael Berlemann, Kalina } \\
\text { Dimitrova, \& Nikolay Nenovsky }\end{array}$ & Mar. 2005 \\
\hline No. 758: Attitudes and Performance: An Analysis of Russian Workers & $\begin{array}{l}\text { Susan J. Linz and Anastasia } \\
\text { Semykina }\end{array}$ & Mar. 2005 \\
\hline $\begin{array}{l}\text { No. 757: Barter, Credit, and Welfare: A theoretical inquiry into the } \\
\text { barter phenomenon in Russia }\end{array}$ & José Noguera and Susan J. Linz & Mar. 2005 \\
\hline $\begin{array}{l}\text { No. 756: Sorting, Selection, and Transformation of the Return to } \\
\text { College Education In China }\end{array}$ & $\begin{array}{l}\text { Belton M. Fleisher, Haizheng Li, } \\
\text { Shi Li, and Xiaojun Wang }\end{array}$ & Mar. 2005 \\
\hline $\begin{array}{l}\text { No. 755: Foreign Exchange Interventions in Emerging Europe: } \\
\text { Should We Give a Damn? The Case of Croatia and Turkey }\end{array}$ & Balázs Égert and Maroje Lang & Mar. 2005 \\
\hline $\begin{array}{l}\text { No. 754: Targeting Relative Inflation Forecast as Monetary Policy } \\
\text { Framework for Adopting Euro }\end{array}$ & T. Orlowski & Feb. 2005 \\
\hline $\begin{array}{l}\text { No. 753: Internet Entrepreneurship: Networks and Performance of } \\
\text { Internet Ventures In China }\end{array}$ & Bat Batjargal & Feb. 2005 \\
\hline $\begin{array}{l}\text { No. 752: Network Triads: Transitivity, Referral and Venture Capital } \\
\text { Decisions in China and Russia }\end{array}$ & Bat Batjargal & Feb. 2005 \\
\hline $\begin{array}{l}\text { No. 751: Software Entrepreneurship: Knowledge Networks and } \\
\text { Performance Of Software Ventures In China and Russia }\end{array}$ & Bat Batjargal & Feb. 2005 \\
\hline $\begin{array}{l}\text { No. 750: Retained State Shareholding in Chinese PLCs: Does } \\
\text { Government Ownership Reduce Corporate Value? }\end{array}$ & Lihui Tian and Saul Estrin & Feb. 2005 \\
\hline No. 749: Financial Development and Technology & Solomon Tadesse & Feb. 2005 \\
\hline No. 748: Banking Fragility and Disclosure: International Evidence & Solomon Tadesse & Feb. 2005 \\
\hline $\begin{array}{l}\text { No. 747: Consolidation, Scale Economies and Technological Change in } \\
\text { Japanese Banking }\end{array}$ & Solomon Tadesse & Feb. 2005 \\
\hline $\begin{array}{l}\text { No. 746: Trade Creation and Diversion Effects of Europe’s Regional } \\
\text { Liberalization Agreements }\end{array}$ & Yener Kandogan & Feb. 2005 \\
\hline No. 745: Quality of Institutions, Credit Markets and Bankruptcy & Christa Hainz & Feb. 2005 \\
\hline $\begin{array}{l}\text { No. 744: How Transition Paths Differ: Enterprise Performance in Russia } \\
\text { and China }\end{array}$ & Sumon Bhaumik and Saul Estrin & Jan. 2005 \\
\hline $\begin{array}{l}\text { No. 743: Inflation Targeting, Between Rhetoric and Reality. The Case } \\
\text { of Transition Economies }\end{array}$ & Daniel Daianu and Laurian Lungu & Jan. 2005 \\
\hline $\begin{array}{l}\text { No. 742: How Does Law Affect Finance? An Empirical Examination of } \\
\text { Tunneling in an Emerging Market }\end{array}$ & $\begin{array}{l}\text { Vladimir Atanasov, Conrad S. } \\
\text { Ciccotello, \& Stanley B. Gyoshev }\end{array}$ & Jan. 2005 \\
\hline $\begin{array}{l}\text { No. 741: Do Insider Trading Laws Matter? Some Preliminary } \\
\text { Comparative Evidence }\end{array}$ & Laura Nyantung Beny & Jan. 2005 \\
\hline
\end{tabular}

